\title{
Nocturnally active western rock lobsters Panulirus cygnus forage close to shallow coastal reefs
}

\author{
Lachlan D. MacArthur ${ }^{1, *}$, Glenn A. Hyndes ${ }^{1}$, Russell C. Babcock ${ }^{2}$, Mathew A. Vanderklift ${ }^{2}$ \\ ${ }^{1}$ Centre for Marine Ecosystems Research, Edith Cowan University, 270 Joondalup Drive, Joondalup, Western Australia 6027, \\ Australia \\ ${ }^{2}$ CSIRO Marine and Atmospheric Research, Private Bag 5, Wembley, Western Australia 6913, Australia
}

\begin{abstract}
The western rock lobster Panulirus cygnus is an abundant consumer along the lower west coast of Australia, sheltering in reef during the day and foraging in surrounding habitat at night. We used acoustic telemetry to determine the distances from high-relief reef where nocturnally active P. cygnus forage at 3 sites representing 3 common shallow-water habitats: meadows of the seagrasses Amphibolis spp. and Posidonia sinuosa and macroalga-dominated pavement. We focussed on among-site variation in core and total nocturnal activity area, distance of foraging from high-relief reef and total distance between position estimates. We found that $P$. cygnus moved over an extensive area at all sites and that $90 \%$ of lobster activity occurred within $60 \mathrm{~m}$ of the nearest high-relief reef at all 3 sites regardless of habitat type. Foraging activity by $P$. cygnus is therefore likely to be greatest within this zone around coastal reefs. Core (50\% utilisation distribution [UD]) and total (95\% UD) nocturnal activity areas did not differ significantly between sites and averaged $2556 \pm 482 \mathrm{~m}^{2}$ and $10437 \pm 2221 \mathrm{~m}^{2}$, respectively. Total distance between position estimates and average distance from reef did not differ between sites either.
\end{abstract}

KEY WORDS: Spiny lobster · Movement $\cdot$ Foraging range

Resale or republication not permitted without written consent of the publisher

\section{INTRODUCTION}

The movement of consumers between distinct habitats to forage can constitute an important link in marine food webs (Polis et al. 1997, Rilov \& Schiel 2006, Valentine et al. 2007). Consumers that use structurally complex habitats such as reefs as shelter often forage in surrounding sand and seagrass habitats (e.g. Randall 1965, Cobb 1981, McAfee \& Morgan 1996, Meyer et al. 2000). As a consequence of this foraging, prey densities may decrease in these habitats when they are adjacent to favoured shelter (e.g. Randall 1965, Edgar 1990b, Langlois et al. 2005). The effect of this foraging tends to decrease with increasing distance from the reef, with the potential for halos of reduced prey density to be produced around reefs (e.g. Randall 1965, Posey \& Ambrose 1994, Langlois et al. 2005). Gaining knowledge of the spatial extent of these types of movements could provide valuable insight into the processes that influence the productivity and biodiversity in, and the scale of connectivity among, the mosaic of habitats that can occur at the landscape scale in the marine environment.

Lobsters are often abundant consumers on temperate and sub-tropical reefs, and can exert a profound impact on benthic communities (e.g. Robles 1987, Edgar 1990a, Babcock et al. 1999). Lobsters typically move between their 'dens' (shelters within reefs) and surrounding benthic habitat at night to forage (Herrnkind 1980). The distances they move away from shelter, and the area they cover while foraging, are likely to be influenced by the density and distribution of prey, energetics of locomotion, time constraints, and the density and activity patterns of predators (Smith et al. 2001). The level of activity and scale of movement may also be influenced by a range of environmental factors such as temperature, moon phase and light intensity (cf. Morgan 1974, 1978, Jernakoff 1987, 
MacDiarmid et al. 1991, Smith et al. 1998, Watson et al. 1999, Srisurichan et al. 2005).

The western rock lobster Panulirus cygnus is an abundant consumer along the lower west coast of Australia, and forms the basis of Australia's largest single species fishery (de Lestang \& Melville-Smith 2006). For at least 3 to 4 yr post-settlement, these lobsters occupy shallow $(<20 \mathrm{~m})$ coastal waters (Chittleborough 1970), which comprise a mosaic of habitats, including high-relief limestone reefs, seagrass meadows, bare sand flats and flat pavement reef (Sanderson 2000, Carruthers et al. 2007). Here, lobsters occupy caves and ledges on, or at the base of, high-relief limestone reefs during the day and forage in surrounding habitat at night (Cobb 1981, Jernakoff 1987, Edgar 1990a). P. cygnus has also been shown to significantly reduce the densities of epifaunal gastropods in seagrass meadows adjacent to reefs (Edgar 1990b); however, it is not known how far this foraging impact extends from the reef edge. Whilst nocturnal foraging movements were quantified with a high degree of accuracy by Jernakoff et al. (1987) at a shallow site dominated by the seagrasses Amphibolis spp. and Halophila ovalis/Heterozostera tasmanica, distance from the reef was not presented; thus, it is difficult to interpret how far the boundary of foraging effort extends from the reef habitat. In addition to meadows of Amphibolis spp. and H. ovalis/H. tasmanica, shallow $(<20 \mathrm{~m})$ reefs are often found associated with another structurally distinct and major habitat-forming seagrass genera, Posidonia (Kirkman \& Walker 1989, Carruthers et al. 2007), as well as areas of limestone pavement dominated by macroalgae and bare sand, which are common in deeper and more exposed areas.

The present study was designed to determine the scale of nocturnal foraging movements of Panulirus cygnus between reef and surrounding habitat. At present, there are few studies that have quantified the distances that reef predators, including lobsters, move into surrounding habitats to forage. Such information is necessary to understand the scale of connectivity between habitats in marine landscapes, an important topic of research, since trophic connectivity can play an important role in maintaining biodiversity and food webs (see Polis et al. 1997). Using acoustic telemetry, lobsters were tracked at 3 sites with distinct habitats that typify the shallow coastal waters of the lower west coast of Australia: meadows of the seagrasses Amphibolis spp. and Posidonia sinuosa and macroalga-dominated pavement (Carruthers et al. 2007). From this, we quantified the scale of total lobster movement and the distance of movement from reef and foraging area, and compared sites with different habitat characteristics. Finally, we investigated the influence of swell height, temperature, moon phase and sex on the spatial extent of lobster nocturnal activity.

\section{MATERIALS AND METHODS}

Study area. The study sites were located within the Jurien Bay Marine Park (30 17.3' S, $\left.115^{\circ} 02.5^{\prime} \mathrm{E}\right)$ on the lower west coast of Australia (Fig. 1). The marine park is representative of the central west region, which is at the centre of the range of Panulirus cygnus, and comprises a mosaic of high-relief limestone reefs, seagrass meadows, areas of flat pavement reef and bare sand. Lobsters were tagged at 3 sites (Fig. 1) in which the vegetated habitat and high-relief reef edge $(>1 \mathrm{~m})$ was determined by SCUBA surveys and towed underwater video. Two of these sites, namely Booker Valley and Boullanger Island, were located in lobster no-take zones (i.e. closed to fishing activities), to allow lobsters to be tracked in the absence of baited pots, which have been shown to influence P. cygnus movements (Jernakoff \& Phillips 1988). Lobsters at the third site, Jurien Basin, were only tracked during times when no baited pots were in the area.

Booker Valley was located $\sim 400 \mathrm{~m}$ from the mainland (Fig. 1) in a no-take zone and consisted of high-relief reef ( $>1 \mathrm{~m}$ ) surrounded by a seagrass meadow of predomi-

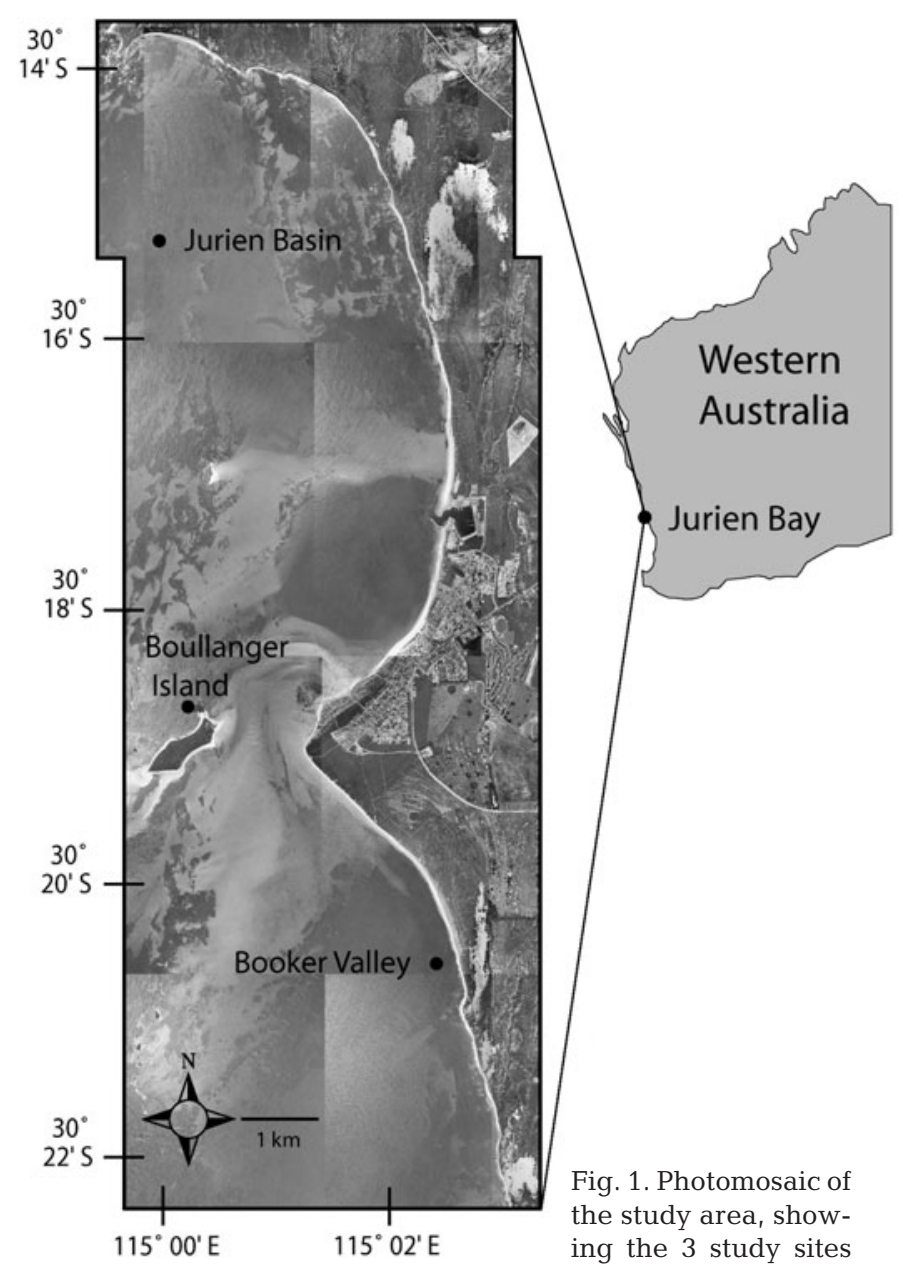


nantly Amphibolis spp. at depths of 3 to $5 \mathrm{~m}$. The top of the reef was covered mainly with algal turf, macroalgae and Amphibolis spp. The reef's vertical walls were covered by algae, sponges, ascidians and other sessile invertebrates.

The Boullanger Island site was located within a no-take zone, $\sim 1.8 \mathrm{~km}$ away from the mainland, and comprised a rocky headland (part of Boullanger Island) with fringing limestone reef (Fig. 1). The habitat around the reef comprised Posidonia sinuosa meadow, which extended to a depth of $7 \mathrm{~m}$. The reef was covered with macroalgae (mainly Ecklonia radiata), sponges, ascidians and other sessile invertebrates. Numerous smaller reef outcrops were also present within 20 to $50 \mathrm{~m}$ from the headland adjacent to where the lobsters were tagged.

Jurien Basin was located $\sim 2.5 \mathrm{~km}$ from the mainland (Fig. 1) and was open to all forms of fishing. The site consisted of a subtidal reef, rising from 10 to $13 \mathrm{~m}$ to $\sim 4 \mathrm{~m}$ at the shallowest point and was surrounded by areas of flat reef pavement, which supported a community of mainly red foliose and articulated coralline algae (e.g. Grateloupia, Pterocladia, Kallymenia, Haliptilon, Amphiroa, Rhodymenia, Hypnea, Erythromenia and Peyssonnelia) as well as patches of Ecklonia radiata and bare sand substrata. Macroalgae (mainly E. radiata), sponges, ascidians and other sessile invertebrates were present on the high-relief reef.

As well as differing in their surrounding habitat, each reef supported different densities of Panulirus cygnus. Six SCUBA surveys of Boullanger Island and Jurien Basin and 5 surveys of Booker Valley (each comprising four $30 \times 5 \mathrm{~m}$ belt transects) were conducted between November 2004 and August 2006. These surveys revealed that Booker Valley had a significantly higher density of $P$. cygnus between 30 and $90 \mathrm{~mm}$ carapace length (CL) (mean \pm SE: $17.57 \pm$ 4.67 per $\left.100 \mathrm{~m}^{2}\right)$, than Boullanger Island $(5.89 \pm 2.12$ per $\left.100 \mathrm{~m}^{2}\right)$ or Jurien Basin $\left(2.75 \pm 1.26\right.$ per $\left.100 \mathrm{~m}^{2}\right)$ (ANOVA, df $=2,16, F=7.22, \mathrm{p}=0.007$ ).

Tagging. On and February 20 and 21, 2007, 15 rock lobsters between 69 and $84.5 \mathrm{~mm} \mathrm{CL}$ (median: $78 \mathrm{~mm}$ ) were tagged with acoustic transmitters (V13H, Vemco), which transmitted continuously at frequencies between 63 and $78 \mathrm{kHz}$ in periods ranging from 1930 to $2000 \mathrm{~ms}$ (Table 1). Lobsters were caught by SCUBA divers and snares and brought back to a boat for tagging. The transmitters were attached to the lobsters using cable ties, with 2 cable ties fastened around the carapace, either side of the 3rd and 4 th pairs of walking legs; further ties were used to fasten these to the transmitters. Kelly (2001) used the same technique successfully for the lobster Jasus edwardsii. This technique has been shown to have no adverse effects on lobster feeding behaviour over a period of weeks, but in a laboratory trial reduced feeding was noted within $4 \mathrm{~d}$ after tagging (MacArthur et al. 2008). The sex and CL of each lobster was recorded, and a section of a pleopod was removed for determination of moult stage. Analysis of these pleopods later in the laboratory revealed that all lobsters were in intermoult stage (using the criteria of Dall \& Barclay 1977), and thus were likely to be actively feeding, since foraging activity is greatest for Panulirus cygnus during this stage (Chittleborough 1975). The tagging process took $<2 \mathrm{~min}$, and lobsters were allowed to adjust to the process for 5 to $30 \mathrm{~min}$ in a shaded holding tank before being returned to the water within $50 \mathrm{~m}$ from where they were caught.

Tracking. Tracking commenced $4 \mathrm{~d}$ after tagging (February 20, 2007) to give the tagged lobsters time to adjust to tagging and handling. Lobsters were tracked using an acoustic receiver (VR100, Vemco) and a directional hydrophone (VH110, Vemco) from a $7 \mathrm{~m}$ boat. The hydrophone was attached to an aluminium pole that was inserted through a cylindrical bracket fastened to the side of the boat. This allowed 
the hydrophone to be rotated 360 degrees. A compass fastened to the top of the pole allowed the user to determine the bearing at which the hydrophone was facing. Lobsters were located by setting the receiver to the desired frequency and rotating the hydrophone until the strongest signal was received. The boat was then slowly driven on that bearing until the signal reached peak strength, indicating that the lobster was under the boat, at which time the position of the boat was marked by GPS. A pilot study using a weighted acoustic transmitter at the Boullanger Island site indicated that accuracy in locating the tag using this method averaged $( \pm$ SE) $8.0 \pm 2.1$ m over 20 trials.

Lobsters were tracked over 3 nights at Booker Valley and Jurien Basin and over 4 nights at Boullanger Island (Table 1). On each night, tracking commenced at sunset and finished just before sunrise, thereby covering nearly all hours of darkness. Every effort was made to obtain position estimates for each lobster consecutively to ensure that each one had the same amount of time devoted to estimating its position and that these position estimates were made over roughly equal intervals during the night. The number of nights that were suitable for tracking was greatly reduced due to strong prevailing south to south-easterly winds that hampered the ability to precisely manoeuvre the boat and thus accurately locate the position of greatest signal strength.

Environmental variables. The average swell height over each of the tracking nights was calculated using swell data from the Department for Planning and Infrastructure, Western Australia (Jurien Bay Buoy No. 40, $\left.42 \mathrm{~m}, 30^{\circ} 17.50^{\prime} \mathrm{S}, 114^{\circ} 54.87^{\prime} \mathrm{E}\right)$. Swell height ranged between 0.57 and $1.70 \mathrm{~m}$ during the study, with a mean of $1.06 \mathrm{~m}$. This compared to a range of 0.36 to $5.70 \mathrm{~m}$ and a mean of $1.89 \mathrm{~m}$ for the entire year of 2006. Water temperature was logged automatically when a position estimate was saved on the GPS unit (Garmin GPS 178C). Water temperatures over the course of the study ranged from 20.3 to $24.7^{\circ} \mathrm{C}$, with a mean of $22.7^{\circ} \mathrm{C}$. Mean monthly water temperature between 1990 and 1994 at a site adjacent to Boullanger Island, at a depth of $5 \mathrm{~m}$, ranged between 18.3 and $22.2^{\circ} \mathrm{C}$ (Pearce et al. 1999). The moon phase on each of the tracking nights was recorded as being 'full' or 'not full'. A night was judged to belong to the full moon phase if the date was closer to that of the full moon than to that of the first or last quarter.

Data analysis. Position estimates were used to calculate the linear distance travelled by each lobster over each night during the tracking period. Position estimates for each lobster were also plotted onto habitat maps of each site, and the distances between each point and the nearest high-relief reef edge (i.e. lobster shelter habitat) were determined.
Fixed kernel estimates of nocturnal activity range (Worton 1989) using least-squares validation as a smoothing parameter (Seaman \& Powell 1996) were calculated for each lobster on each night when >5 position estimates were made using The Home Ranger program (Ursus Software). To view the shape of these areas and the position in relation to high-relief reef habitat, the 95 and $50 \%$ utilisation distribution (UD) contours, representing total and core activity areas, respectively, were then plotted onto maps of each site using the program OziExplorer (D \& L Software). The area within these contours was also calculated.

The following nocturnal activity parameters, averaged over nights for each lobster, were compared between sites using analysis of variance (ANOVA) in SPSS V.13: total distance between position estimates, distance of position estimates from nearest high-relief reef and 95 and $50 \%$ UD areas. As obtaining position estimates was easier at Jurien Basin, due to its habitat characteristics, and the total distance travelled for individual lobsters was positively correlated with the number of position estimates obtained $\left(\mathrm{R}^{2}=0.632, \mathrm{p}<0.001\right)$, the number of position estimates was used as a covariate when performing ANOVA on total distance data. Where differences between sites were found to exist at $\mathrm{p}<$ 0.05, Tukey's honestly significant difference pairwise test was used to determine the nature of the differences among sites.

We performed a distance-based redundancy analysis (dbRDA; Legendre \& Anderson 1999, McArdle \& Anderson 2001), using the DistLM option in the PRIMER 6 \& PERMANOVA + $\beta 4$ software package (PRIMER-E), to determine if the following predictor variables-CL:sex, moon phase (full vs. not full), mean nightly swell height and mean nightly water temperature-explained a significant level of variation in the 50 and $95 \%$ UD areas of lobsters. This technique allows multiple regression to be performed on any distance or dissimilarity response matrix of choice (McArdle \& Anderson 2001). We used Euclidean distance as the distance measure to compare the variables (50 and 95\% UD areas) among samples (individual lobster foraging nights) and to construct a resemblance matrix on which the predictor variables were tested. Variables were first tested individually for a significant effect (marginal tests), then added sequentially to the model using Akaike's information criterion (AIC; Akaike 1974) as the selection criterion (conditional tests). The proportion of total variation in the matrix explained by predictor variables was tested for significance by obtaining p-values from 9999 unrestricted permutations of the matrix column and row labels (sample labels). 


\section{RESULTS}

\section{Detection of lobsters}

A total of 11 lobsters were tracked for up to 4 nights each (Table 1), and 364 position estimates were made. Two lobsters tagged at the Jurien Basin site were caught in commercial lobster pots, and their tags were returned before they were able to be tracked. Two lobsters tagged at Booker Valley could not be located due to very weak or non-existent signals, which, in conjunction with high background noise at that site, prevented position estimates from being made. Lobster 5 from Boullanger Island left the study site on the first night of tracking, but was tracked moving to a more offshore reef $\sim 700 \mathrm{~m}$ from the first position estimate. No further position estimates were made for Lobster 5 after this time, due to the dangers associated with tracking this lobster around this shallow reef at night.

\section{Nocturnal activity areas}

There was considerable variation in the size, shape, position and number of core (50\% UD) and total (95\% UD) activity areas displayed by lobsters at all sites (Fig. 2). Some lobsters had multiple core activity areas, e.g. Lobsters 1 and 2 at Boullanger Island, whilst others had single core activity areas, e.g. Lobsters 3 and 4 at the same site. Total activity areas were always adjacent to, or overlapping, subtidal reef a

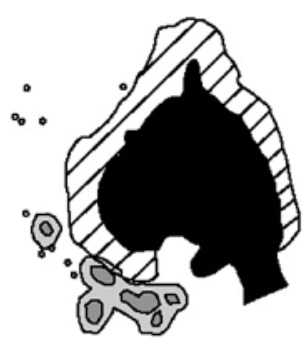

Lobster $1(2,12)$

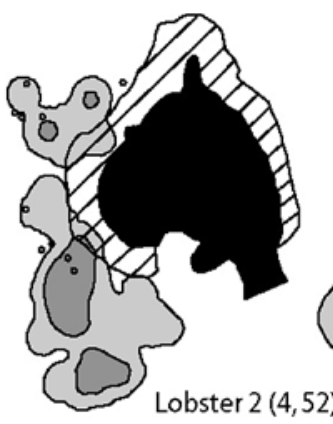

Lobster $2(4,52)$

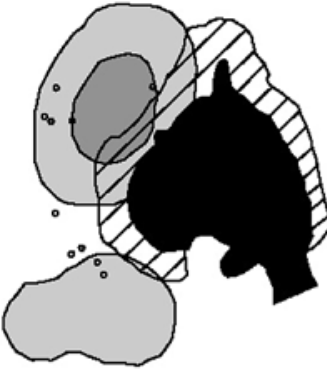

Lobster $3(3,25)$

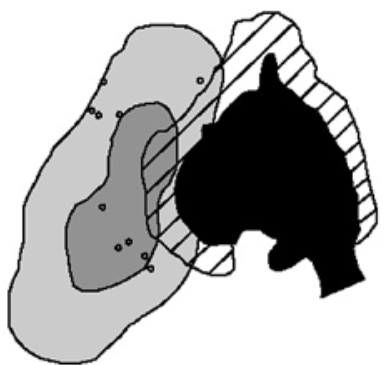

Lobster $4(3,29)$
(0)<smiles>C1=CC=CCCCC=C1</smiles>

b



Lobster $2(1,5)$

C

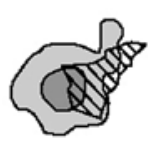

Lobster $2(2,36)$

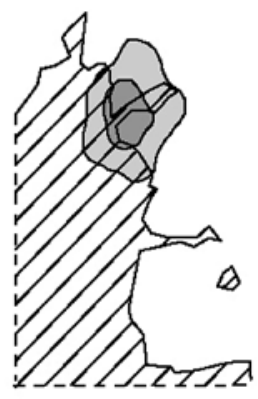

Lobster $3(3,28)$

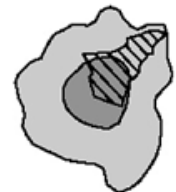

Lobster $3(3,70)$
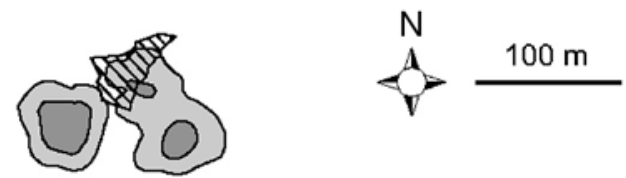

Fig. 2. Panulirus cygnus. The 50\% (core) and 95\% (total) fixed kernel utilisation distributions (UD) for lobsters tracked at (a) Boullanger Island, (b) Booker Valley and (c) Jurien Basin between February and April 2007, using data combined over all nights. In parentheses: number of nights tracked, then number of position estimates 
with the exception of Lobster 4 at Booker Valley, where 3 total activity areas were away from the reef edge. There was as much variability in the position of activity areas for each lobster as there was between lobsters at each site (Fig. 2). Core foraging areas for individual lobsters were separated by distances of up to $\sim 250 \mathrm{~m}$.

\section{Distance from reef edge}

The median distance between high-relief reef and position estimates for each lobster was $<20 \mathrm{~m}$, with the single exception of Lobster 5 from Jurien Basin, which had a median distance from high-relief reef of $35 \mathrm{~m}$ (Fig. 3). Furthermore, 75\% of the position estimates for each lobster were always $<45 \mathrm{~m}$ from reef. In comparison, the 90th percentile was highly variable ranging between 18 and $88 \mathrm{~m}$, indicating that there was considerable variation in the furthest extent of lobster movement from the nearest high-relief edge, but that large movements were rare. Pooling data for each lobster at each site revealed that $90 \%$ of positions were within $52 \mathrm{~m}$ at Boullanger Island, $29 \mathrm{~m}$ at Booker Valley and $42 \mathrm{~m}$ at Jurien Basin (Fig. 3). Furthermore, the median distance of position estimates away from high-relief reef were 16, 6 and $14 \mathrm{~m}$ for Boullanger Island, Booker Valley and Jurien Basin, respectively (Fig. 3).

\section{Comparison of activity parameters between sites}

The mean $( \pm \mathrm{SE})$ total linear distance between nightly position estimates for lobsters was $241.9 \pm 24.9$ $\mathrm{m}$ at Boullanger Island, 231.6 $\pm 30.2 \mathrm{~m}$ at Booker Valley and $443.3 \pm 20.8 \mathrm{~m}$ at Jurien Basin (Fig. 4a). When number of position estimates was used as a covariate there was no statistical difference between these values $(F=0.145$, df $=2,10, \mathrm{p}=0.868)$. The average distance of position estimates from reef for each lobster was not found to differ significantly between sites $(F=$ 0.921, $\mathrm{df}=2,9, \mathrm{p}=0.441$ ) and ranged from $9.4 \pm 6.4 \mathrm{~m}$ (Booker Valley) to $19.5 \pm 2.1 \mathrm{~m}$ (Boullanger Island) (Fig. 4b). Average total nocturnal activity areas (95\% UD) ranged from $6588 \pm 2070 \mathrm{~m}^{2}$ (Jurien Basin) to $15396 \pm 4116 \mathrm{~m}^{2}$ (Boullanger Island), and average core nocturnal activity areas (50\% UD) ranged from $1823 \pm$ $632 \mathrm{~m}^{2}$ (Booker Valley) to $3661 \pm 868 \mathrm{~m}^{2}$ (Boullanger Island) (Fig. 4c,d). None of these values differed significantly (95\% UD: $F=2.083$, df $=2,9, \mathrm{p}=0.195$; $50 \%$ UD: $F=2.163$, df $=2,9, \mathrm{p}=0.186$ ). Total nightly activity area averaged across all lobsters was $10437 \pm$ $2221 \mathrm{~m}^{2}$, and core nightly activity area averaged across all lobsters was $2566 \pm 482 \mathrm{~m}^{2}$.
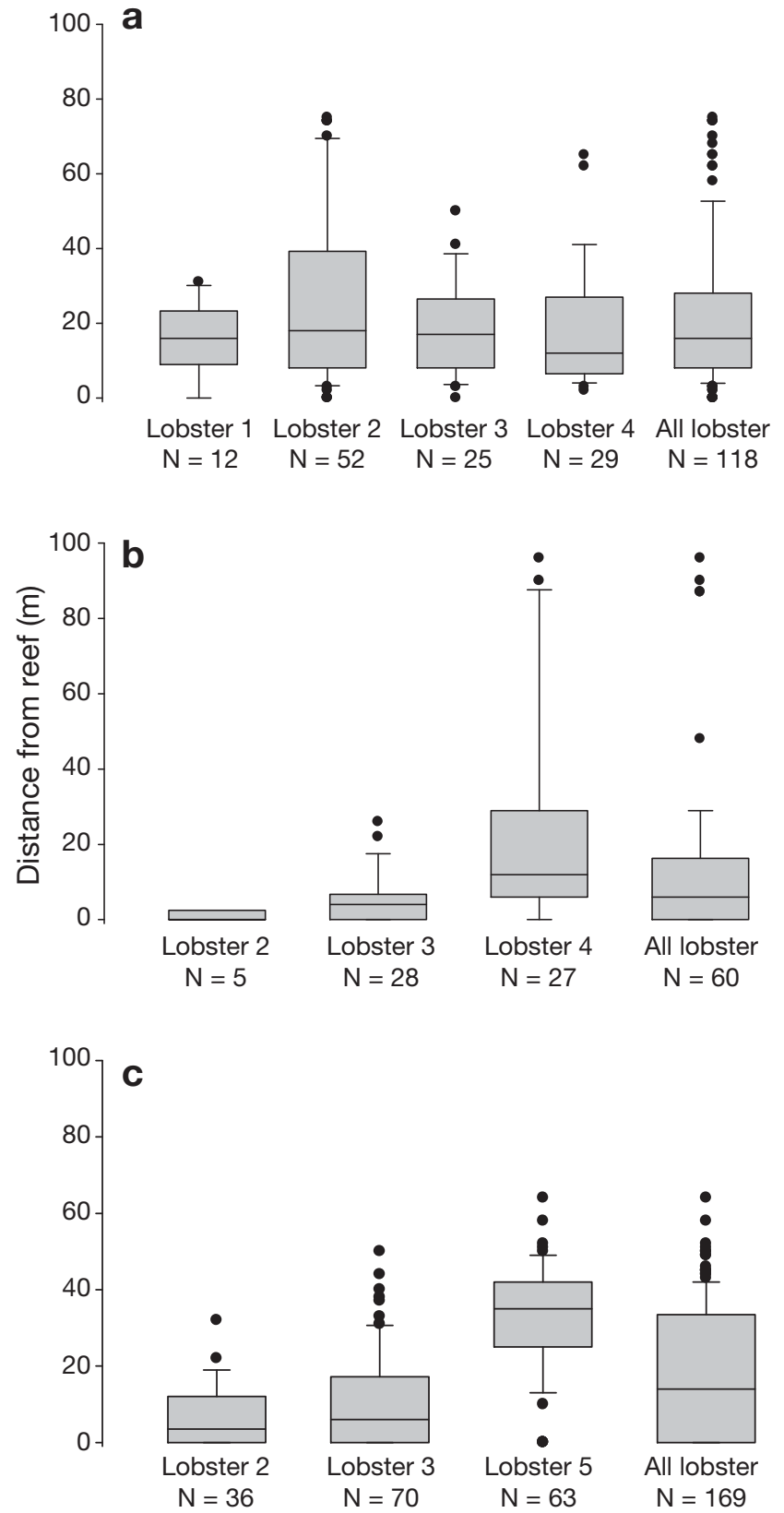

Fig. 3. Panulirus cygnus. Box-and-whisker plots for each lobster tracked at (a) Boullanger Island, (b) Booker Valley and (c) Jurien Basin, showing median distance from reef edge together with $10,25,75$ and 90th percentiles and outliers

\section{Effect of predictor variables on lobster nocturnal activity areas}

The variables of CL, sex, mean nightly water temperature, mean nightly swell height (Swell) and moon phase (Moon) neither individually nor cumulatively explained a significant amount of variation in the 50 or $95 \%$ UD areas of lobsters ( $p \geq 0.130$; Table 2). 

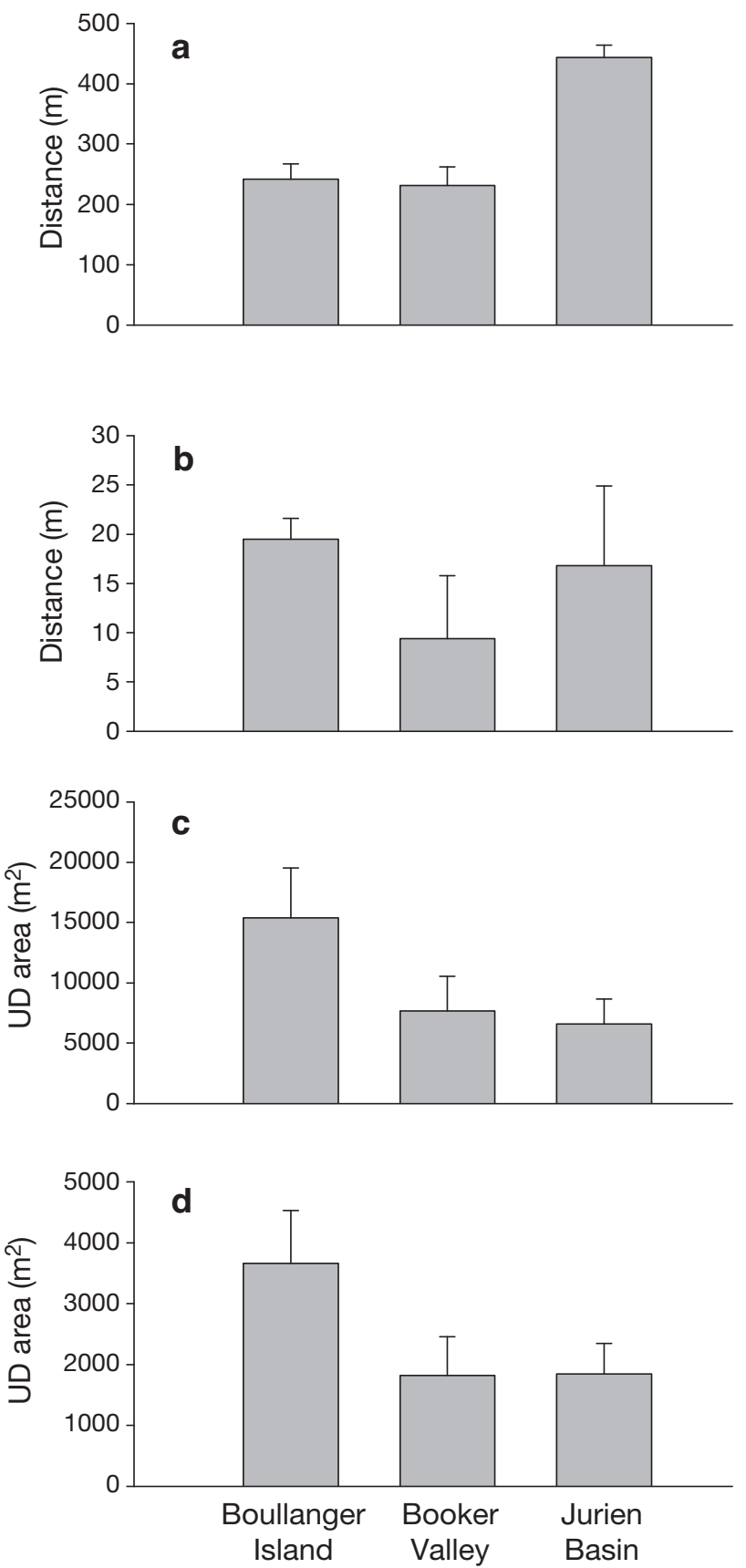

Fig. 4. Panulirus cygnus. Nocturnal activity parameters of individual lobsters averaged over 3 sites: (a) total distance between position estimates, (b) average distance between position estimates and high-relief reef, (c) $95 \%$ utilisation distribution (UD) area and (d) $50 \%$ UD area. Data means + $1 \mathrm{SE}$

\section{DISCUSSION}

The present study indicates that the spatial distribution of nocturnal foraging by Panulirus cygnus is strongly influenced by the location of high-relief reef habitat where they shelter during the day. At each site, $90 \%$ of all position estimates were located within
Table 2. Panulirus cygnus. Results from a distance-based redundancy analysis showing the proportion of total variation (\%) in 50 and $95 \%$ utilisation distribution (UD) areas, and associated p-values, explained by 5 variables fitted: individually to the model (marginal tests) and sequentially to the model using Akaike's information criterion as the selection criterion for inclusion (conditional tests). SS: sum of squares

\begin{tabular}{|lcccc|}
\hline Variable & SS (trace) & Pseudo- $F$ & $p$ & $\%$ \\
\hline Marginal tests & & & & \\
CL & $1.387 \times 10^{7}$ & 0.105 & 0.749 & 4.36 \\
Sex & $7.582 \times 10^{7}$ & 0.586 & 0.485 & 2.38 \\
Temp. & $3.011 \times 10^{8}$ & 2.5109 & 0.130 & 9.47 \\
Swell & $1.992 \times 10^{8}$ & 1.604 & 0.240 & 6.26 \\
Moon & $6.204 \times 10^{7}$ & 0.478 & 0.572 & 1.95 \\
Conditional tests & & & \\
Temp. & $3.011 \times 10^{8}$ & 2.5109 & 0.130 & 9.47 \\
\hline
\end{tabular}

$60 \mathrm{~m}$ of high-relief reef, and only 2 out of 10 lobsters were located further away than this for $>10 \%$ of the night. No lobsters that remained at the study sites moved further than $100 \mathrm{~m}$ from the reef edge. In comparison, the mean nightly total distance travelled by lobsters at each of the sites (231.6 to $443.3 \mathrm{~m}$ ) was over an order of magnitude larger than the mean distance travelled away from the reef edge (9.4 to $19.5 \mathrm{~m}$ ), indicating that movement occurs within a relatively narrow band around reef-shelter habitat. Further support for this comes from the location of core nightly activity areas, which were nearly always adjacent to, and often overlapped, the edge of high-relief reef. The consistency of these results between sites with different surrounding benthic habitat and densities of lobsters indicates that they are likely to be broadly applicable to reefs within shallow coastal regions along the lower west coast of Australia. The finding that lobsters are nocturnally active in Posidonia sinuosa and macroalga-dominated pavement habitat suggests that these habitats, which are commonly adjacent to reef in coastal waters, are used as foraging habitats by lobsters in addition to Amphibolis spp. and Heterozostera/ Halophila habitat (Jernakoff 1987, Edgar 1990a).

The estimates of total distance travelled by Panulirus cygnus each night in the present study encompassed a similar range to those calculated for this species at a shallow water (2 to $3 \mathrm{~m}$ ) site dominated by Amphibolis spp. and Heterozostera/Halophila seagrasses (Jernakoff et al. 1987). That study found 95\% of lobsters moved between 72.5 and 585 m (median: $310 \mathrm{~m})$ each night, compared to averages $( \pm \mathrm{SE})$ of $231.6 \pm 30.2,241.9 \pm 24.9$ and $443.3 \pm 20.8 \mathrm{~m}$ for Booker Valley, Boullanger Island and Jurien Basin, respectively. Total distance values presented here are not likely to be as accurate as those by Jernakoff et al. (1987), where an array of electromagnetic receivers were used, due to less frequent position estimates and 
the larger errors associated with estimating position. However, both studies suggest that $P$. cygnus typically move over distances of up to 100s of metres compared to 10s of metres as reported by Chittleborough (1974). Such discrepancies may be partly due to different site characteristics, but are almost certainly related to the methods used, since baited traps were used by Chittleborough (1974) to determine foraging range, and have since been shown to influence the natural movement patterns of $P$. cygnus (Jernakoff \& Phillips 1988). The present study provides further evidence that $P$. cygnus undertakes foraging movements of a similar magnitude to the congeneric Caribbean spiny lobster P. argus (100s of metres; Herrnkind 1980), but of an order of magnitude larger than New Zealand spiny lobsters, Jasus edwardsii (10s of metres; MacDiarmid et al. 1991).

The concentration of nocturnal activity within $100 \mathrm{~m}$ of reef edge, with most (90\%) activity occurring $<60 \mathrm{~m}$ from the reef edge, suggests that there is a potential for the densities of a range of small invertebrate prey items, such as gastropods, bivalves, small crustaceans and polychaetes, to be reduced within this zone (Joll \& Phillips 1984, Edgar 1990a). Indeed, densities of the gastropod Cantharidus lepidus have been experimentally shown to be significantly reduced by Panulirus cygnus foraging (Edgar 1990b), and surveys within the present study area have shown this gastropod species to be significantly more abundant $>100 \mathrm{~m}$ away from the edge of patch reefs (F. Tuya unpubl. data). Evidence for lobster-mediated halos of reduced prey density has also been provided by Langlois et al. $(2005,2006)$, who found densities of the bivalve prey Drosinea subrosea to be lower $<10 \mathrm{~m}$ away from New Zealand rocky reefs. Future research into this field will benefit from the type of data collected in the present study, allowing surveys or experimental manipulations of prey communities to be directed across a known gradient of lobster foraging activity. It is important to note, however, that lobster predation may not necessarily be the most important factor controlling the abundance of prey communities adjacent to lobster shelter habitat (e.g. Nizinski 2007), since a suite of other factors likely influence their distribution and abundance (see Langlois et al. 2005, Nizinski 2007).

The use of a relatively narrow band at the edge of reef and surrounding habitat may be related to the presence of predators or distribution of preferred prey. Panulirus cygnus of the size studied here use undercut ledges and caves at the edge of high-relief limestone reef as shelter during the day (Cobb 1981). This is likely to decrease the chance of attack from predators, since shelter increases survival of spiny lobsters (Eggleston et al. 1990). Natural mortality of P. cygnus between age classes is approximately $50 \%$ for the size range studied here (Phillips et al. 2003), and predation is thought to be one of the main factors driving mortality (Howard 1988). Remaining close to reef at night may therefore be advantageous for $P$. cygnus, decreasing the time taken to reach shelter if attacked. Little is known of the key natural predators of P. cygnus, although some predators, such as the sand bass Psammaperca waigiensis, octopus Octopus tetricus and wobbegong Orectolobus spp., are nocturnally active (Howard 1988, Last \& Stevens 1994, Anderson 1997, Carraro \& Gladstone 2006). Escaping these and other predators may be an important factor determining the spatial distribution of foraging effort. In addition, the edge of high-relief reef may yield additional food to surrounding habitat, and staying within close proximity of this boundary would decrease the time necessary to access food in both habitats. Indeed dietary studies of $P$. cygnus from the area reveal a range of food types, including invertebrates and algae, from both seagrass and reef (L. MacArthur unpubl. data). The present study adds to a wide range of studies that have shown habitat edges to be important predictors of organism distribution patterns within landscapes (see Ries et al. 2004).

Our study has shown that neither CL, sex, moon phase, water temperature, nor swell height affected the nocturnal activity area of lobsters. Temperature and sex have been shown to affect Panulirus cygnus movement (Morgan 1978, Jernakoff 1987), whilst swell height and moon phase have been shown to affect catchability (Morgan 1974, Srisurichan et al. 2005). The effect of these variables on the foraging area of P. cygnus, however, has not previously been studied. Since this study was conducted over a relatively short time period and relatively small changes in swell height and water temperatures were encountered, we cannot rule out these factors influencing natural foraging movement across a greater range. However, it does suggest that $P$. cygnus foraging area is not sensitive to small fluctuations in these variables.

The present study suggests that if protection of legal-sized P. cygnus is a goal of no-take zones, then ecotones between reef and surrounding habitat should be included, as they serve as important areas for both shelter and foraging. The use of reef edge as boundaries for no-take zones cannot be recommended based on our results, rather boundaries should be set away from the reef edge allowing a buffer for foraging. Our results indicate that $100 \mathrm{~m}$ would be necessary to enclose all foraging movements, however, since baited pots can attract down-current lobsters up to $120 \mathrm{~m}$ away (Jernakoff \& Phillips 1988), at least this distance again would likely be necessary to ensure complete protection. 


\section{CONCLUSIONS}

The spatial distribution of nocturnally active Panulirus cygnus within shallow coastal waters is strongly influenced by the presence of high-relief shelter reef, with most lobsters utilising a relatively narrow band around reef $(\sim 60 \mathrm{~m})$ most of the time. This pattern was consistent over 3 sites displaying benthic habitats that are dominant along the lower west coast of Australia, i.e. Amphibolis spp., Posidonia spp. and macroalgadominated pavement. The observed spatial distribution of nocturnally active lobsters may be related to food availability and the distribution of predators, but these factors remain untested. Future studies investigating the potential impact of $P$. cygnus foraging on benthic communities may benefit from our findings by allocating sampling effort within and outside areas of high nocturnal lobster density, thereby incorporating a likely gradient of foraging intensity. We suggest that the inclusion of boundaries between reef and surrounding habitat within no-take zones is desirable if protection of $P$. cygnus and their foraging habitats is an aim of these zones.

Acknowledgements. This research was supported by Edith Cowan University and the Strategic Fund for the Marine Environment. Thanks to R. Caccianiga, K. Cook, J. Eyres, N. Schofield, R. Snell, P. van Dyke, K. Waddington and K. Watt for assistance in the field, as well as the Department of Environment and Conservation and the Department of Fisheries, Western Australia, for permits supporting this work.

\section{LITERATURE CITED}

Akaike H (1974) A new look at statistical model identification. IEEE Trans Automat Contr 19:716-723

Anderson TJ (1997) Habitat selection and shelter use by Octopus tetricus. Mar Ecol Prog Ser 150:137-148

Babcock RC, Kelly S, Shears NT, Walker JW, Willis TJ (1999) Changes in community structure in temperate marine reserves. Mar Ecol Prog Ser 189:125-134

Carraro R, Gladstone W (2006) Habitat preferences and site fidelity of the ornate wobbegong shark (Orectolobus ornatus) on rocky reefs of New South Wales. Pac Sci 60: 207-223

- Carruthers TJB, Dennison WC, Kendrick GA, Waycott M, Walker DI, Cambridge ML (2007) Seagrasses of southwest Australia: a conceptual synthesis of the world's most diverse and extensive seagrass meadows. J Exp Mar Biol Ecol 350:21-45

Chittleborough RG (1970) Studies on recruitment in the western rock lobster Panulirus longipes cygnus George: density and natural mortality of juveniles. Aust J Mar Freshwater Res 21:131-148

> Chittleborough RG (1974) Home range, homing and dominance in juvenile western rock lobsters. Aust J Mar Freshwater Res 25:227-234

Chittleborough RG (1975) Environmental factors affecting growth and survival of juvenile western rock lobsters Panulirus longipes (Milne-Edwards). Aust J Mar Fresh- water Res 26:177-196

Cobb JS (1981) Behaviour of the Western Australian spiny lobster, Panulirus cygnus George, in the field and laboratory. Aust J Mar Freshwater Res 32:399-409

Dall W, Barclay MC (1977) Induction of viable ecdysis in the western rock lobster by 20-hydroxyecdysone. Gen Comp Endocrinol 31:323-334

de Lestang S, Melville-Smith R (2006) West coast rock lobster managed fishery status report. Department of Fisheries, Western Australia, Perth

- Edgar GJ (1990a) Predator-prey interactions in seagrass beds. I. The influence of macrofaunal abundance and size-structure on the diet and growth of the Western rock lobster Panulirus cygnus George. J Exp Mar Biol Ecol 139:1-22

Edgar GJ (1990b) Predator-prey interactions in seagrass beds. III. Impacts of the western rock lobster Panulirus cygnus George on epifaunal gastropod populations. J Exp Mar Biol Ecol 139:33-42

Eggleston DB, Lipcius RN, Miller DL, Coba-Cetina L (1990) Shelter scaling regulates survival of juvenile Caribbean spiny lobster Panulirus argus. Mar Ecol Prog Ser 62:79-88

Herrnkind WF (1980) Spiny lobsters: patterns of movement. In: Cobb JS, Phillips BF (eds) The biology and management of lobsters, Vol 1. Academic Press, New York, p 349-401

Howard RK (1988) Fish predators of the western rock lobster (Panulirus cygnus George) in a nearshore nursery habitat. Aust J Mar Freshwater Res 39:307-316

Jernakoff P (1987) Foraging patterns of juvenile western rock lobsters Panulirus cygnus George. J Exp Mar Biol Ecol 113:125-144

Jernakoff P, Phillips BF (1988) Effect of a baited trap on the foraging movements of juvenile western rock lobsters, Panulirus cygnus George. Aust J Mar Freshwater Res 39: 185-192

Jernakoff P, Phillips BF, Maller RA (1987) A quantitative study of nocturnal foraging distances of the western rock lobster Panulirus cygnus George. J Exp Mar Biol Ecol 113:9-21

Joll LM, Phillips BF (1984) Natural diet and growth of juvenile rock lobsters Panulirus cygnus George. J Exp Mar Biol Ecol 75:145-169

- Kelly S (2001) Temporal variation in the movement of the spiny lobster Jasus edwardsii. Mar Freshw Res 52:323-331

Kirkman H, Walker DI (1989) Regional studies — Western Australian seagrasses. In: Larkum AWD, McComb AJ, Shepherd S (eds) Biology of seagrasses - a treatise on the biology of seagrasses with special reference to the Australian region. Elsevier, Amsterdam, p 157-181

> Langlois TJ, Anderson MJ, Babcock RC (2005) Reef-associated predators influence adjacent soft-sediment communities. Ecology 86:1508-1519

Langlois TJ, Anderson MJ, Babcock RC, Kato S (2006) Marine reserves demonstrate trophic interactions across habitats. Oecologia 147:134-140

Last PR, Stevens JD (1994) Sharks and rays of Australia. CSIRO Australia, East Melbourne

Legendre P, Anderson MJ (1999) Distance-based redundancy analysis: testing multispecies responses in multifactorial ecological experiments. Ecol Monogr 69:1-24

> MacArthur LD, Babcock RC, Hyndes GA (2008) Movements of the western rock lobster (Panulirus cygnus) within shallow coastal waters using acoustic telemetry. Mar Freshw Res 59:603-613

MacDiarmid AB, Hickey B, Maller RA (1991) Daily movement patterns of the spiny lobster Jasus edwardsii (Hutton) on a shallow reef in northern New Zealand. J Exp Mar Biol Ecol 147:185-205

McAfee ST, Morgan SG (1996) Resource use by five sym- 
patric parrotfishes in the San Blas Archipelago, Panama. Mar Biol 125:427-437

McArdle BH, Anderson MJ (2001) Fitting multivariate models to community data: a comment on distance-based redundancy analysis. Ecology 82:290-297

Meyer CG, Holland KN, Wetherbee BM, Lowe CG (2000) Movement patterns, habitat utilization, home range size and site fidelity of whitesaddle goatfish, Parupeneus porphyreus, in a marine reserve. Environ Biol Fishes 59: 235-242

Morgan GR (1974) Aspects of the population dynamics of the western rock lobster, Panulirus cygnus George. II. Seasonal changes in the catchability coefficient. Aust J Mar Freshwater Res 25:249-259

Morgan GR (1978) Locomotor activity in the western rock lobster, Panulirus longipes cygnus. Aust J Mar Freshwater Res 29:169-174

Nizinski MS (2007) Predation in subtropical soft-bottom systems: spiny lobster and molluscs in Florida Bay. Mar Ecol Prog Ser 345:185-197

Pearce A, Rossbach M, Tait M, Brown RS (1999) Sea temperature variability off Western Australia 1990 to 1994. Fish Res Rep Fish Dep (West Aust) 111:1-45

Phillips BF, Melville-Smith R, Rossbach M, Cheng YW and others (2003) FRDC Project 1998/302-Rock lobster enhancement and aquaculture subprogram: towards establishing techniques for large scale harvesting of pueruli and obtaining a better understanding of mortality rates. Rep No. 144, Department of Fisheries, Western Australia, Perth

Polis GA, Anderson WB, Holt RD (1997) Toward an integration of landscape and food web ecology: the dynamics of spatially subsidized food webs. Annu Rev Ecol Syst 28: 289-316

Posey MH, Ambrose WGJ (1994) Effects of proximity to an offshore hard-bottom reef on infaunal abundances. Mar Biol 118:745-753

Editorial responsibility: Carolyn Burns,

Dunedin, New Zealand
Randall JE (1965) Grazing effect on seagrasses by herbivorous reef fishes in the West Indies. Ecology 46:255-260

Ries L, Fletcher RJ Jr, Battin J, Sisk TD (2004) Ecological responses to habitat edges: mechanisms, models, and variability explained. Annu Rev Ecol Evol Syst 35:491-522

Rilov G, Schiel DR (2006) Trophic linkages across seascapes: subtidal predators limit effective mussel recruitment in rocky intertidal communities. Mar Ecol Prog Ser 327:83-93

Robles C (1987) Predator foraging characteristics and prey population structure on a sheltered shore. Ecology 68: $1502-1514$

Sanderson PG (2000) A comparison of reef-protected environments in Western Australia: the central west and Ningaloo coasts. Earth Surf Process Landf 25:397-419

Seaman DE, Powell RA (1996) An evaluation of the accuracy of kernel density estimators for home range analysis. Ecology 77:2075-2085

Smith IP, Collins KJ, Jensen AC (1998) Electromagnetic telemetry of lobster (Homarus gammarus (L.)) movements and activity: preliminary results. Hydrobiologia 371/372: 133-141

Smith IP, Jensen AC, Collins KJ, Mattey EI (2001) Movement of wild European lobsters Homarus gammarus in natural habitat. Mar Ecol Prog Ser 222:177-186

Srisurichan S, Caputi N, Cross J (2005) Impact of lunar cycle and swell on the daily catch rate of western rock lobster (Panulirus cygnus) using time series modelling. N Z J Mar Freshw Res 39:749-764

- Valentine JF, Heck KL, Blackmon D, Goecker ME and others (2007) Food web interactions along seagrass-coral reef boundaries: effects of piscivore reductions on crosshabitat energy exchange. Mar Ecol Prog Ser 333:37-50

Watson WH III, Vetrovs A, Howell WH (1999) Lobster movements in an estuary. Mar Biol 134:65-75

Worton BJ (1989) Kernel methods for estimating the utilisation distribution in home-range studies. Ecology 70 : $164-168$

Submitted: February 6, 2008; Accepted: October 24, 2008 Proofs received from author(s): November 30, 2008 